\title{
Analyze of the Effect of Workplace Spirituality on Auditor Dysfunctional Behavior and its Implication to Audit Quality
}

\author{
Bawono Yudyanto Arief Kusumo \\ The Audit Board of the Republic of Indonesia \\ Poppy Sofia Koeswoyo \\ Department of Accounting - Faculty of Economics and Business \\ Universitas Padjadjaran \\ Sofik Handoyo \\ Department of Accounting - Faculty of Economics and Business \\ Universitas Padjadjaran
}

\begin{abstract}
This study aims to analyze the effect of workplace spirituality on auditor dysfunctional behavior and its implication to audit quality at The Audit Board of The Republic of Indonesia. The research approach used is quantitative and casual design. The number of research samples was 92 auditors taken through proportionate sampling. The data analysis used descriptive and inferential statistical analysis by employing path analysis. The results show that there is a significant negative effect of workplace spirituality on dysfunctional auditor behavior, there is a significant positive effect of workplace spirituality on audit quality, and there is a significant negative effect of dysfunctional auditor behavior on audit quality. The conclusions of the study state that there is a significant effect of workplace spirituality on dysfunctional auditor behavior. Implication to audit quality is that the audit quality can be improved through workplace spirituality and dysfunctional auditor behavior
\end{abstract}

Keywords: Workplace spirituality; Auditor; Dysfunctional behavior; Audit quality

\section{Introduction}

The auditor is a profession that provides services to the public, especially users of financial statements, among others: investors, creditors, candidates, and creditor government or institutions (Boynton \& Kell, 2006). As a profession, the auditor is responsible for the trust given by the users of the financial statements, so the auditor needs to ensure that the audit report is qualified (Frohnen \& Clare, 2002). According to
Vanstraelen (2000), audit quality is the auditor's ability to detect and report material misstatements in sample inspection during the audit process; then auditors are not only required to detect but also to report material misstatements. Audit failure occurs when the auditor provides an audit opinion, not in line with the fact that it does not meet the auditing standards specified (Arens et al., 2012).

Previous studies have generally shown a threat to degradation of audit quality due to dysfunctional behavior that auditors 
sometimes perform in auditing tasks (Pierce \& Sweeney, 2004; Sweeney \& Pierce, 2010). Dysfunctional behavior is an action performed by auditors in implementing audit standards that potentially reduce audit quality, either directly or indirectly (Kelley, 1990; Otley \& Pierce, 1996). According to Donnelly, et al. (2003), auditor dysfunctional behavior continues to grow and is already at the stage of interrupting the auditor profession, and even according to Otley \& Pierce (1995) has led to a disruption of audit quality.

Dysfunctional behavioral conditions of the auditor do not just happen but are at least influenced by workplace spirituality. The public auditor or accountant in carrying out his professional duties must perform the standard of inspection and adhere to the professional code of ethics in order to maintain the audit quality. When acting for public accountants must meet and apply the basic principles and applicable professional ethics. However, in reality, there are still many different conditions, namely the occurrence of dysfunctional auditor behavior or a massive auditor. In anticipating this, Hartman and Desjardins (2011) state the existence of the primary application of fundamental thinking, as well as the potential to reduce the dysfunctional behavior. Emerson and McKinney (2010) express the importance of returning to religious beliefs in behavior after in practical ethics is not capable of being a moral keeper in the business world. Religious values will make the work more useful and meaningful. In this perspective, working not only to meet the needs of material merely but as a form of sacrifice for the benefit of society. A faithful public accountant and putting forward spiritual values that are partially reflected in professional, ethical codes and inspection standards will be able to give opinions more meaningful so that they can be trusted in important decision-making processes.

The above description shows the urgency of workplace spirituality in order to suppress the dysfunctional auditor behavior and to improve the audit quality, including the audit quality by auditors at The Audit Board of The Republic of Indonesia (BPK), which oversees the management and accountability of state finances. It is very crucial, considering that there are still so many corruption cases involving government officials. As an example of the phenomenon that occurred in the case of Tomohon Mayor Jefferson Rumajar was proven to bribe two BPK auditors where on May 21, 2012, the judges sentenced the verdict four years six months and four years respectively to 2 defendants auditor BPK Representative of North Sulawesi (TribunManado, 21 May 2012).

Also, the Panel of Corruption Court judges sentenced every four years to two BPK auditors of West Java at the hearing on 8 November 2010 (Detikcom, 8 November 2010) in the bribery case of giving an opinion of the WTP (Unqualified Opinion) of Bekasi District Government Financial Report of 2009. Based on this urgency, researchers are interested in examining the effect of workplace spirituality on the dysfunctional auditor behavior and its implications on the audit quality by taking a unit of BPK auditor analysis.

\section{Literature Review}

\section{Workplace Spirituality and Auditor Dysfunctional Behavior}

Sulistyo's research (2014) entitled "Relevansi Nilai Religius Dalam Mencegah Perilaku Disfungsional Audit" found that there is a relationship between spiritual influence on dysfunctional auditor behavior. Auditor dysfunctional behavior arises due to the low ethical orientation of the auditor, requiring an unsteady ethical value that can prevent dysfunctional auditor behavior. This unsteady ethical value can be found in a religion that comes from God. Religion proved to play a role in reducing acts that are 
far from the truth; this happens because someone with high religiosity has selfmonitoring, self-control, and self-regulation thanks to the knowledge of the Supreme Power that always pays attention (God). The results of Purnamasari and Amaliah research (2015) under the title "Fraud prevention: relevance to religiosity and spirituality in the workplace" with a sample of BPKP auditors of West Java Province also show that workplace spirituality has a significant effect on fraud prevention. The results of the research by McGhee \& Grant (2008) with the title "Spirituality and Ethical Behavior in the Workplace: Wishful Thinking or Authentic Reality," also show that workplace spirituality leads to increased ethical behavior (personal and organizational), thus avoiding the dysfunctional behavior.

\section{Spirituality and the Audit Quality}

Earnest research, Farhana \& Saat (2015) "Assessing the Relationship Between Human Capital and Spiritual Capital on Firm's Performance Audit," the results show that both human capital and spiritual capital provides a significant positive correlation to the performance of the audit in the company. Research Mappanyuki (2016) entitled "Effects of Spiritual Influence of Auditors, Complexity Task, Ethics Auditor and Auditor Expertise on The Performance Auditor with Accounting Information Systems with moderating variables (Empirical Study on BPK Representative Office South Sulawesi)" the results also showed a significant association between the influence of the auditor's spiritual on the auditor's performance. Notoprasetio research results (2012) with the title "Pengaruh Kecerdasan Emosional dan Kecerdasan Spiritual Auditor Terhadap Kinerja Auditor pada Kantor Akuntan Publik di Surabaya." the results also show that there is significant influence emotional and spiritual intelligence on the performance of auditors. Similarly, the results of research and Setiawan, Latrini (2016) with the title "Pengaruh Kecerdasan Emosional, Kecerdasan Spiritual, Kecerdasan Intelektual dan Independensi pada Kinerja Auditor," conducted in Bali KAP describe the spiritual acumen positive effect on the performance of auditors. Then, the Ahmadi study et al. (2014) entitled "The Relationship Between Spirituality in The Workplace and Organizational Citizenship Behavior" also shows that workplace spirituality affects organizational citizenship behavior, including auditor's auditing behavior.

\section{Dysfunctional Behavior and Audit Quality}

Research Kustinah (2013) entitled "The Influence of Dysfunctional Behavior and Individual Culture on Audit Quality." The study used a survey method conducted by distributing questionnaires to respondents who were determined purposively. Data analysis used correlation and regression. The results show that dysfunctional behavior affects audit quality. Separately, dysfunctional behavior has a negative and significant effect on audit quality. Utary's study (2014) entitled "Effect of Time Budget Pressure on Dysfunctional Audit and Audit Quality, Information Technology as Moderate," also shows that dysfunctional behavior affects the audit quality

\section{The Research Framework}

Empirically the audit quality can be influenced by workplace spirituality and dysfunctional auditor behavior. A person who has high religiosity has self-control thanks to the knowledge of the Supreme Power that keeps on watching God tends to avoid dysfunctional behavior (Sulistyo, 2014) and produces high audit quality (Notoprasetio, 2012; Earnest, Farhana \& Saat, 2015; and Mappanyuki, 2016). Moreover, high dysfunctional behavior can 
degrade audit quality (Kustinah, 2013). Thus, workplace spirituality can reduce dysfunctional behavior resulting in high audit quality. Audit quality in the context of this study is the ability of the auditor to detect and report material misstatement in the audit of the quotation test during the audit process based on the skills, experience, ethical value, mindset, method reliability, tool effectiveness and availability of technical support used by the auditor in performing the task audit.

Based on the discussed literature on workplace spirituality, dysfunctional auditor behavior, and audit quality in the previous section, the research questions set in this study are: 1) How does workplace spirituality have a significant negative relationship with dysfunctional auditor behavior? 2) How does workplace spirituality have a significant positive relationship with audit quality? 3) How does dysfunctional auditor behavior have a significant negative relationship with audit quality?

Audit quality in the context of this study is the ability of the auditor to detect and report material misstatement in the audit of the quotation test during the audit process based on the skills, experience, ethical value, mindset, method reliability, tool effectiveness and availability of technical support used by the auditor in performing the task audit. The constellation of causal relationships between these variables can be described in the conceptual framework of research as follows:

Figure 1. The Research Framework

Exogenous Variable Endogenous Variable

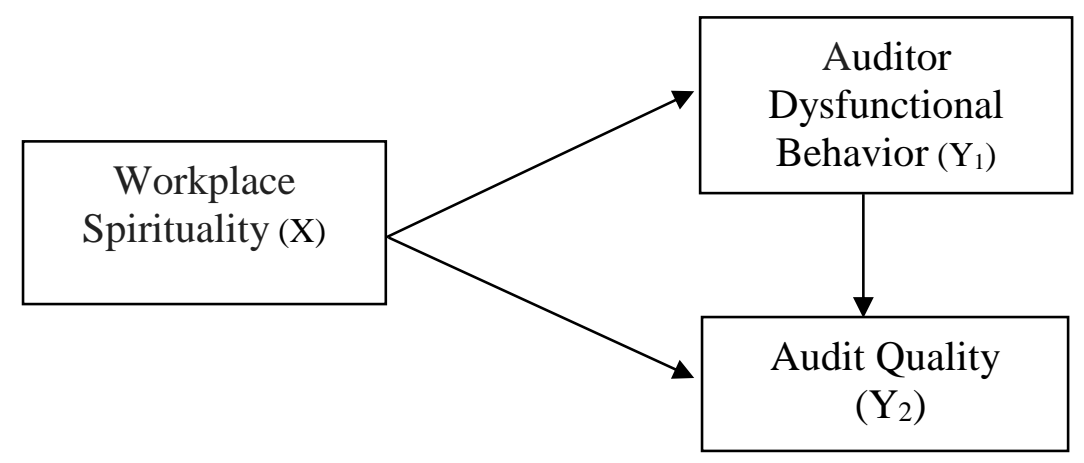

\section{Methodology}

This research uses a quantitative approach or positivistic paradigm (Denzin \& Lincoln, 2003). Quantitative paradigms are rooted in the positivist thinking pioneered by Comte, Mill, and Durkheim (Neumann, 2010). The quantitative approach aims to see the relationship between these variables. The use of research approach aims to assist researchers in evaluating the extent to which the data produced through certain methods that accurately and truly reflect the reality (Poerwandari, 2001). Thus this research uses a causal design in the form of path analysis. The type of data of this research is primary data, which is sourced from 92 respondents as the research quote test. The research quote was taken from the study population, which is 1,181 auditors at The Audit Board of The Republic of Indonesia (BPK) working at the BPK Head Office as of 1 September 2016, 
divided into six levels of a role in the Functional Position of Auditor (JFP). Taking the number of quotation tests using the Slovin formula (in Umar, 2006: 108). From the results of the calculation is known, the number of quotation test is 92 auditors. Testing is done proportionate sampling based on the following roles.

Field research was conducted to obtain primary data through a questionnaire distributed to the research respondents, that is BPK auditors working at the Jakarta Head Office. The questionnaire was made in the form on a Likert scale with five alternative answers, namely: Always (SL), Frequent (SR), Sometimes (KK), Rarely (JR), and Never (TP). The questionnaire contains 54 statements derived from 3 variables then filled by the respondents. Scores are given in the lowest range 1 and the highest five by giving the score for positive statements given the highest score five if the respondent's answer SL then successive SR score 4, KK score 3, JR score 2 and TP score 1 . Whereas in the negative statement score The highest five if the respondent's answer TP then successively JR score 4, KK score 3, SR score, and SL score 1. Besides that, there is a modification of the variable statement Audit Quality item on the dimension of knowledge and experience. In the dimension of knowledge, the highest score five on the understanding of the overall 4 points stated, while the experience dimension is the highest score is given on the longer duration of the auditor and the more varied types of audit ever undertaken.

\section{Results}

\section{Cronbach's Alpha Test of Reliability}

Reliability test among variable should be conducted in order to test the dependent of variables used in a data. Based on reliability test performed, all variable ranked above 0.7 the threshold (Pallant, 2007). The Cronbach's alpha for workplace spirituality (26 items) is 0.949 , dysfunctional auditor behavior is 0.926 (10 items), and audit quality (22 items) is 0.957 . Value of 0.9 above shown they have very good internal consistency reliability for the scale with this sample. As mentioned by Pallant (2007), values above 0.7 are considered acceptable; however, values above 0.9 are preferable.

\section{Descriptive Analysis}

Table 1 shows descriptive results on workplace spirituality. The highest percentage achieved is 75.22 on the statement of 'Enjoyment at work.' It is followed by 'Team's sense of community" with a percentage of 74.86. Overall, the percentage of all the items indicate that the workplace spirituality respondents only reached $72.71 \%$ of the $100 \%$, so it still needs to be improved.

Table 1. Findings Workplace Spirituality

\begin{tabular}{llcc}
\hline No & Item & Score & Percentage \\
\hline 1 & Team's sense of community & 2.066 & 74,86 \\
2 & Alignment with organizational values & 1.688 & 73,39 \\
3 & Sense of contribution to society & 1.594 & 69,30 \\
4 & Enjoyment at work & 1.038 & 75,22 \\
5 & Opportunities for inner life & 1.641 & 71,35 \\
Average & & $\mathbf{7 2 , 7 1}$ \\
\hline
\end{tabular}


While Table 2 shows the results of dysfunctional auditor behavior. The highest percentage achieved is 74.35 on the statement of 'Under-Reporting of Time (URT)".
Overall, the percentage of all the items indicate that the dysfunctional auditor behavior of the respondents reached $74.18 \%$ of the $100 \%$, so it still needs to be reduced.

Table 2. Findings Auditor Dysfunctional Behavior

\begin{tabular}{|c|c|c|c|}
\hline No & Pernyataan & Score & Percentage \\
\hline 1 & Audit Quality Reduction & 2.387 & 74,13 \\
\hline \multirow[t]{2}{*}{2} & Under Reporting of Time (URT) & 684 & 74,35 \\
\hline & Average & & 74,18 \\
\hline
\end{tabular}

Table 3 shows descriptive results on audit quality. The highest percentage achieved is 74.42 on the statement of "Reliability of methods used." This is followed by 'The effectiveness of the tools used" with a percentage of 73.04. Overall, the percentage of all the items indicate that the audit quality only reached $68.20 \%$ of $100 \%$, so it still needs to be improved.

Table 3. Findings Audit Quality

\begin{tabular}{llll}
\hline No & Item & Score & Percentage \\
\hline 1 & Knowledge & 1.573 & 68,39 \\
2 & Experience & 624 & 67,83 \\
3 & Ethical Values & 1.511 & 65,70 \\
4 & Mindset & 899 & 65,14 \\
5 & Reliability of methods used & 1.027 & 74,42 \\
6 & The effectiveness of the tools used & 672 & 73,04 \\
7 & Availability of technical support & 282 & 61,30 \\
\multicolumn{2}{l}{ Average } & & $\mathbf{6 8 , 2 0}$ \\
\hline
\end{tabular}

\section{Path Diagram}

The correlation between workplace spirituality, dysfunctional auditor behavior, and audit quality were significant at the $\alpha=$ 0.05 level (1-tailed). Importantly, it has shown that there exists a positive and a negative relationship between the tested variables. Specifically, workplace spirituality $\left(\rho=-0.59^{* *}\right)$ shows the most substantial negative relationship between dysfunctional auditor behavior, followed by dysfunctional auditor behavior on audit quality $(\rho=$ $\left.0.51^{* *}\right)$. Additionally, between workplace spirituality to audit quality, there is a significant positive relationship $\left(\rho=0.27^{* *}\right)$. 
Figure 2. The Correlations between Variables

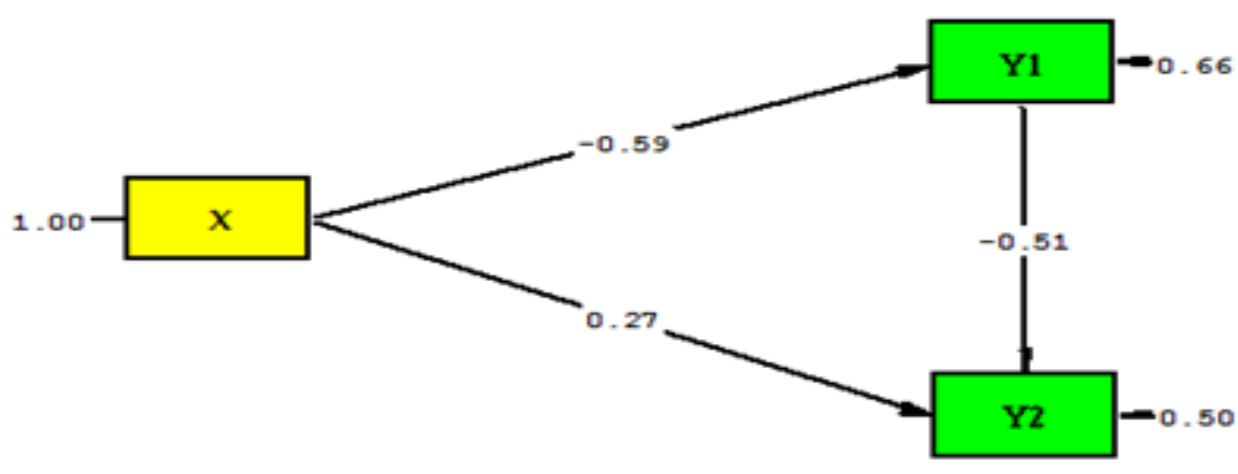

Chi-Square=0.00, df=0, P-value=1.00000, RMSRA=0.000

\section{Discussion and Conclusions}

This study aimed to examine whether there exists a relationship between workplace spirituality and dysfunctional auditor behavior on audit quality. Besides that, to examine whether there exists a relationship between workplace spirituality on dysfunctional auditor behavior. Statistical analysis (Path Diagram) performed revealed that both workplace spirituality $(\mathrm{t}$ values $=2.92>\mathrm{t}$ table 1,661 $(\alpha 0,05)$ and auditor dysfunctional behavior $(\mathrm{t}$ values $=-5,57>\mathrm{t}$ table 1,661 $(\alpha$ $0,05)$ sequences do have a significant positive relationship and a significant negative relationship with audit quality. Then, that workplace spirituality $-6,88>\mathrm{t}$ table $1,661(\alpha$ $0,05)$ do have a significant negative relationship with dysfunctional auditor behavior.

Figure 3. The Relationships between Variables

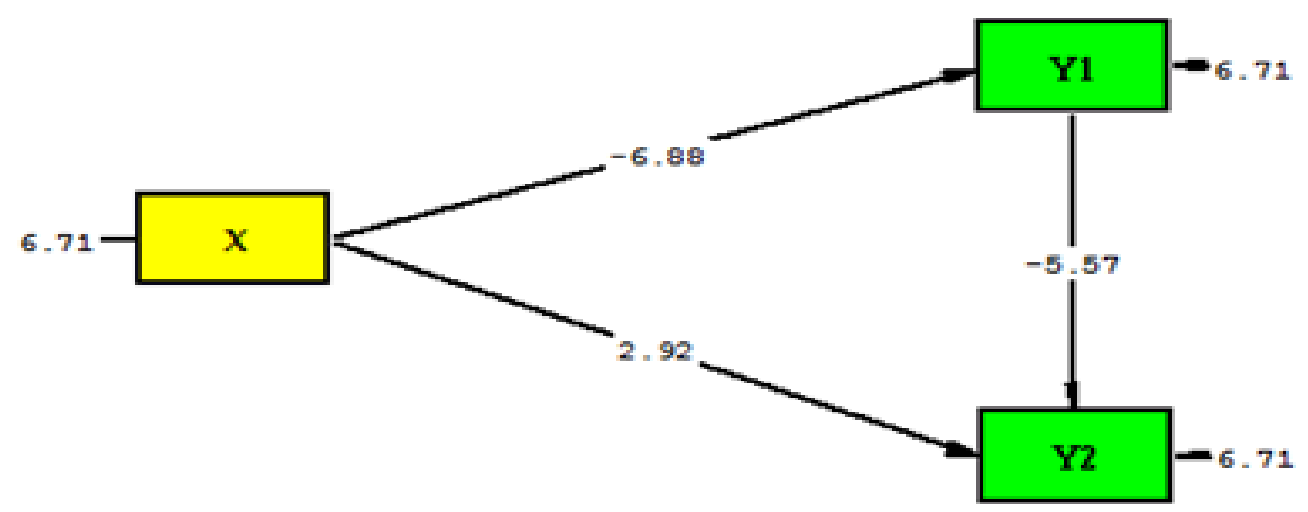

Chi-Square=0.00, df=0, P-value=1.00000, RMSEA-0.000 
The results of this study indicate that workplace spirituality has a negative effect on dysfunctional auditor behavior. Workplace spirituality is the recognition that employees have a core of life that motivates them and is motivated by meaningful work in society (Asmos \& Duchon, 2000). When the auditor owns the condition of such spirituality, it can reduce the dysfunctional auditor behavior. These findings are aligned with and under previous relevant research results by Sulistyo (2014), Purnamasari and Amaliah (2015), and McGhee and Grant (2008) that workplace spirituality can degrade potential auditor dysfunctional behavior. Thus, the results of this study support and confirm previous research on the effect of workplace spirituality on dysfunctional auditor behavior.

This study also shows that workplace spirituality has a positive effect on audit quality. Workplace spirituality is an acknowledgment that employees have a core of life that motivates them and is motivated by meaningful work in society (Asmos \& Duchon, 2000). When such a condition of spirituality is possessed the auditor may encourage the improvement of the audit quality as the ability of the auditor to detect and report material misstatement in the audit of the quotation test during the inspection process (Vanstraelen, 2000).

These findings are consistent with and in accordance with previous research conducted by Earnest, Farhana \& Saat (2015), Mappanyuki (2016), Notoprasetio (2012), Setiawan and Latrini (2016) and Ahmadi, et al (2014), supporting and confirming previous research on the influence of workplace spirituality on the audit quality.

Also, the results of this study prove that dysfunctional auditor behavior affects audit quality. Auditor dysfunctional behavior is any action performed by the auditor during the conduct of inspection procedures that may reduce the audit quality, either directly or indirectly (Kelley \& Margheim, 1990; Otley \& Pierce, 1996a). When the dysfunctional auditor behavior does not occur or at least under minimal conditions, the audit quality is maintained better, since the audit quality is usually related to the ability of the auditor to detect and report material misstatement in the audit of the quotation test during the inspection process (Vanstraelen 2000). Strictly speaking, is the absence of dysfunctional behavior will ensure better audit quality.

This finding is consistent with previous relevant research results conducted by Kustinah (2013) and Utary (2014) that dysfunctional behavior affects the audit quality. Thus, the results of this study support and confirm previous research on the effect of dysfunctional behavior affect audit quality.

From the results of the analysis and discussion that have been described previously, then the conclusions of the findings of this study are as follows: 1) Workplace spirituality negatively affects the dysfunctional auditor behavior. These findings suggest that improvements in the form of increased workplace spirituality can distract dysfunctional auditor behavior. 2) Workplace spirituality positively affects audit quality. These findings suggest that improvements in the form of increased workplace spirituality can improve audit quality. 3) Auditor dysfunctional behavior has a negative effect on audit quality. These findings suggest that dysfunctional auditor behavior may degrade the audit quality. 


\section{References}

Ahmadi, S., Nami, Y., \& Barvarz, R. (2014)," The Relationship Between Spirituality in The Workplace and Organizational Citizenship Behavior," Procedia - Social and Behavioral Sciences 114 ( 2014 ) 262 $-264$

Ashmos, D. \& Duchon, D., 2000. Spirituality at Work. A Conceptualization and Measure. Journal of Management Inquiry, $\quad 9(2)$, 134-145. http://search.ebscohost.com.

Chen, Yi-Pei Liu, Chu -Yang Chien. 2009. The association between auditor quality and human capital. Managerial Auditing Journal. Vol. 24 No. 6. pp. $523-541$

Earnest, D. F., Chamian, N. F, dan Saat, M. M., 2015. "Assessing The Relationship Between Human Capital And Spiritual Capital On Audit Firm's Performance." Jurnal Kemanusiaan, Vol. 24: Issue 2, 18-28.

Fairholm, G. W.: 1996, Spiritual leadership: fulfilling whole-self needs at work. Leadership and Organization Development Journal. Vol. 17 (5); pp. 11-17.

Fry, L. W. \& Matherly, L. L. (2006). Spiritual Leadership and Organizational Performance. Paper presented at the Academy of Management, Atlanta, Georgia.

Garcia-Zamor, J. (2003), “Workplace spirituality and organizational performance", PublicAdministration Review, Vol. 63 No. 3, pp. 355-63.

Giacalone, R. A., \& Jurkiewicz, C. L. (2004). "A values framework for measuring the impact of workplace spirituality on organizational performance." Journal of Business Ethics, 49, 129142.

Hayes, R, Dassen, R, Schilder, A. \& Wallage, P. (2005). Principles of Auditing. An Introduction to International Standards of Auditing,2nd Edition, Ed. Pearson Education.

Herrbach, O., 2001. "Audit Quality, Auditor Behaviour, and the Psychological Contract. European Accounting Review. Vol. 10 No. 4. pp. 787-802.

Kelley, T., Margheim Loren, 1990, "The Relationships Between Senior Auditor Budget Participation, Job Structuring, Job Consideration And Staff Auditor Time Budget Pressure" The Journal of Applied Business Research Volume 18, Number 2, 1990

Korac-Kakabadse, N. Kouzmin, A., Kakabadse, A. (2002). Spirituality and leadership praxis. Journal of Managerial Psychology, 17(3), 165182.

Kumpikaitė - Valiūnienèa, Vilmantè. (2014). "Spirituality at work: comparison analysis," Procedia Social and Behavioral Sciences 150, 1205-1212

Kustinah, S., 2013. The Influence of Dysfunctional Behavior and Individual Culture on Audit Quality. International Journal Of Scientific \& Technology Research Volume 2, Issue 5, 2013 ISSN 2277-8616, 118125 .

Malone, C.F., and Robert, R. W., 1996. "Factors Associated With the Incidence of Reduced Audit Quality Behavior." Auditing: A Journal of 
Practice and Theory. Vol. 15. No. 2: pp. 49-64.

Mappanyuki, Ratna. 2016. Effects Spiritual Influence Of Auditors, Complexity Task, Ethics Auditor And Auditor Expertise On The Performance Auditor Withaccounting Information Systems With Moderating Variabel (Empirical Study on BPKP Representative Office South Sulawesi). Southeast Asia Journal of Contemporary Business, Economics, and Law, Vol. 9, Issue 1, 2289-1560, $28-43$.

McGhee P. and Grant, P. (2008), "Spirituality and Ethical Behavior in the Workplace: Wishful Thinking or Authentic Reality," EJBO Electronic Journal of Business Ethics and Organization Studies. Vol. 13 No. 2, pp. 61-69.

McNair, C.J., 1991. Proper Compromises: The Management Control Dilemma in Public Accounting and its Impact on Auditor Behavior. Accounting, Organizations, and Society 16 (7):635-653.

Milliman, J., Czaplewski, A.J. \& Ferguson, J. (2003), "Workplace spirituality and employee work attitudes: an exploratory empirical assessment," Journal of Organizational Change Management, Vol. 16 No. 4, pp. 42647.

Mitroff, I. (2003). Do not promote religion under the guise of spirituality. The organization, 10(2), 375-382.

Neck, C.P., and Milliman, J.F.:1994, "Thought self-leadership: finding spiritual fulfillment in organizational life," Journal of Managerial Psychology, Vol. 9. No. 6, pp. 9-16.
Notoprasetio, Christina G. 2012. Pengaruh Kecerdasan Emosional dan Kecerdasan Spiritual Auditor Terhadap Kinerja Auditor pada Kantor Akuntan Publik di Surabaya. Jurnal Ilmiah Mahasiswa Akuntansi Vol. 1, No. 4, 2012, 76-81.

Otley, D. W., and B. Pierce, (1995), “The Control Problem in Public Accounting Firms an Empirical Study of Impact of Leadership Style," Accounting, Organizations and Society, 20: 405-420.

Pfeffer, J. (2003), "Business and spirit: management practices that sustain values," in Giacalone, R.A. and Jurkiewicz, C.L. (Eds), The Handbook of Workplace Spirituality and Organizational Performance, M.E. Sharpe, Armonk, NY.

Poerwandari, K. (2001), Pendekatan Kualitatif untuk Penelitian Perilaku Manusia, Jakarta: LPSP3 UI.

Purnamasari, P. dan Amaliah, I. (2015), "Fraud prevention: relevance to religiosity and spirituality in the workplace," Procedia - Social and Behavioral Sciences 211 ( 2015 ) 827 $-835$

Setiawan, Y. G. dan Latrini, M. Y. (2016), "Pengaruh Kecerdasan Emosional, Kecerdasan Spiritual, Kecerdasan Intelektual Dan Independensi Pada Kinerja Auditor," E-Jurnal Akuntansi Universitas Udayana Vol.16.2. Agustus (2016): 1034-1062.

Strack, G., Fottler, M.D., Wheatley, M.J. \& Sodomka, P. (2002). Spirituality and EffectiveLeadership in Healthcare: Is there a Combination? Frontiers of Health Services Management, 18(4),3-17. 
Sulistyo, Heru. 2014. Relevansi Nilai Religius Dalam Mencegah Perilaku Disfungsional Audit. Jurnal Ekonomi Manajemen dan Akuntansi. No. 36 / Th. XXI / April 2014, 1-13.

Utary, A. R., Effect of Time Budget Pressure on Dysfunctional Audit and Audit Quality, Information Technology as Moderat, IJER 11(3), July-Dec. 2014: 6 89-698 ISSN: 0972-9380

Zohar, D., \& Marshall, I. (2001). SQ: Spiritual intelligence, the ultimate intelligence. London: Bloomsbury Publishing
Vanstraelen, A. (2000). Impact of Renewable Long Term Audit Mandatory An Audit Quality. The European Accounting Review. 9:419 - 444.

Zohar, D. Marshall, I. (2004), Spiritual Capital: Using our Rational, Emotional, and Spiritual Intelligence to Transform Ourselves and Corporate Culture, Bloomsbury. 